\title{
DAMPAK KARAKTERISTIK SISTEM INFORMASI AKUNTANSI MANAJEMEN PADA KINERJA MANAJERIAL
}

\author{
Lorina Siregar Sudjiman dan Paul Eduard Sudjiman \\ Fakultas Ekonomi, Universitas Advent Indonesia
}

\begin{abstract}
Abstrak
Sistem akuntansi manajemen (SAM) menyediakan informasi bagi manajer untuk memprediksi konsekuensi yang mungkin terjadi dari berbagai kegiatan alternatif tentang Organisasi dan menyediakan mekanisme untuk mengendalikan organisasi. Tujuan dari diskusi ini adalah untuk membahas "dampak informasi tentang karakteristik kinerja SIAM dan membahas manfaat dari sistem akuntansi manajerial bagi manajer". Informasi yang memiliki karakteristik yang baik, seperti broadscope, ketepatan waktu, agregasi, dan integrasi perlu meningkatkan akurasi pengambilan keputusan. manajemen kinerja akan lebih baik jika keputusan manajemen yang tepat. Kedua informasi yang dapat diperoleh dari sistem informasi terarah dan terintegrasi dengan baik, SAM.
\end{abstract}

Kata-kata kunci: Kinerja Manajerial, Akuntansi Manajemen Sistem, Karakteristik Informasi.

\section{CHARACTERISTICS IMPACT OF MANAGEMENT ACCOUNTING INFORMATION SYSTEM ON MANAGERIAL PERFORMANCE}

\begin{abstract}
Management accounting system (SAM) provides information for managers to predict consequences that may occur from a variety of alternative activities on the Organization and provides a mechanism for controlling the organization. The purpose of this discussion is to discuss "the impact of information on the performance characteristics of the SAM and discusses the benefits of systems of managerial accounting for managers". Information that has the characteristics of a good, as broadscope, timeliness, aggregation, and integration it needs to improve the accuracy of decision-making. Performance management would be good if the right management decisions. Both are information can be obtained from the information system of directional and well-integrated, SAM.
\end{abstract}

\section{Pendahuluan}

Informasi suatu perusahaan dalam dunia bisnis mempunyai sasaran utama (Wahyudin, 2007). Kebutuhan informasi dalam suatu perusahaan akan tergantung pada berbagai faktor ketidakpastian lingkungan dan faktor struktur organisasi perusahaan. Salah satu fungsi dari sistem informasi adalah menyediakan informasi penting untuk membantu manajer mengendalikan aktivitasnya sehingga diharapkan dapat membantu perusahaan ke arah pencapaian tujuan dengan sukses.

Informasi sangat berguna bagi perusahaan dalam kegiatan perencanaan, kontrol, dan pengambilan keputusan. Informasi yang dihasilkan suatu sistem informasi merupakan sumber daya bagi organisasi, dimana informasi tersebut dapat mendukung manajemen dalam pengambilan keputusan (Widarsono, 2007). Informasi yang digunakan untuk pengambilan keputusan oleh manajer harus merupakan informasi yang memiliki kualitas atau karakteristik informasi yang baik sehingga pengambilan keputusan tepat dan pada akhirnya dapat meningkatkan kinerja secara keseluruhan. Aksesbilitas dan kapabilitas dalam pengintegrasian infomasi menjadi faktor penting pengambilan keputusan strategis. Organisasi harus mampu mendesain dan mengembangkan sistem informasi yang berkualitas untuk menunjang kinerja. Guimaraes et al. (2003) menyatakan bahwa bisnis mempunyai ketergantungan yang tinggi terhadap sistem informasi yang dikembangkan. Lebih jauh dinyatakan 
Dampak Karakteristik Sistem Informasi Akuntansi Manajemen Pada Kinerja Manajerial

bahwa perlu dilakukan upaya yang terus-menerus dalam menjaga dan memperbaiki kualitas sistem yang saat ini dikembangkan (Person et al, 2001).

Sistem informasi akuntansi manajemen (SIAM) merupakan sistem formal yang dirancang untuk menyediakan informasi bagi manajer (Abernethy, 2000).

Perencanaan SIAM perlu mendapat perhatian yang diharapkan akan memberikan kontribusi positif dalam mendukung keberhasilan sistem pengendalian manajemen yang nantinya akan membantu perusahaan dalam pencapaian tujuan. Perencanaan Sistem Akuntansi Manajemen (SAM) yang merupakan bagian dari sistem pengendalian organisasi perlu mendapat perhatian, hingga penerapannya memberikan kontribusi positif dalam mendukung keberhasilan sistem pengendalian manajemen (Anthony dkk., 1998 \& Faisal, 2006).

Hansen dan Mowen (2006:4) menjelaskan sistem informasi akuntansi manajemen sebagai sistem informasi yang menghasilkan output dengan menggunakan input dan berbagai proses yang diperlukan untuk memenuhi tujuan manajemen. Informasi yang tersedia dan digunakan manajemen sangat membantu para manajer dalam menyelesaikan tugasnya, sehingga diharapkan kinerja akan meningkat. Informasi yang dihasilkan dari sistem informasi dapat digunakan untuk mengukur kinerja ekonomi dari unit organisasi dalam perusahaan. Manfaat utama dari informasi adalah mengurangi ketidakpastian, mendukung keputusan, dan mendorong lebih baik dalam hal perencanaan dan penjadwalan aktivitas kerja.

\section{TELAAH LITERATURE \\ Sistem Informasi Akuntansi Manajemen}

Akuntansi sebagai sistem informasi dan mengkomunikasikan informasi keuangan kepada pihakpihak yang mempunyai kepentingan terhadap organisasi perusahaan dan merupakan instrumen penting bagi dunia bisnis yang akan digunakan sebagai alat bantu dalam pengambilan keputusan bisnis. Sistem informasi akuntansi manajemen (SIAM) memiliki tugas menyediakan informasi yang dibutuhkan untuk memudahkan pengawasan dan tindakan terhadap penilalan organisasi tersebut. Artinya bahwa system informasi akuntansi manajemen merupakan suatu perangkat manusia dan sumber-sumber modal dalam suatu organisasi yang bertanggung jawab untuk menghasilkan dan menyebarkan informasi yang dipertimbangkan relevan di dalam pembuatan keputusan (Supriyono, 2001:72). Pendapat ini dikuatkan oleh Ritonga dan Zainuddin (2002) bahwa sistem informasi akuntansi manajemen merupakan suatu mekanisme pengawasan organisasi yang dapat memudahkan pengawasan dengan cara membuat laporan dan menciptakan tindakan yang nyata terhadap penilaian kinerja dan setiap komponen dalam organisasi. Jadi dengan demikian sistem informasi akuntansi manajemen dapat membantu dalam menghadapi tantangan yang dihasilkan pesaing dalam menghasilkan nilai tambah yang lebih besar dibandingkan pesaingnya, sehingga dengan demikian tujuan utama perusahaan dapat dicapai dengan efektif dan efisien.

Manajemen dalam menjalankan fungsi dan aktivitas bisnisnya yang meliputi Planning (Perencanaan), Organizing (Pengorganisasian), Actuating (Pengarahan), dan Controlling (Pengendalian), senantiasa memerlukan informasi untuk membuat keputusan (Widarsono, 2007)

Dewasa ini dengan meningkatnya tugas pemecahan masalah yang dihadapi oleh manajemen, maka rancangan SIAM tidak hanya berorientasi pada data finansial saja tetapi berorientasi pada data yang bersifat eksternal dan nonfinansial (Mia dan Chenhall, 1994). Diantara karakteristik informasi SAM, informasi broad scope telah teridentifikasi sangat penting dalam membantu pengambilan keputusan manajerial (Chenhall dan Morris 1986; Gordon dan Narayanan 1984).

Kriteria umum mengenai karakteristik informasi yang baik menurut manajemen adalah (Chia, 1995 dan Juniarti \&Evelyne 2003):

\section{Belaah roadscope}

Didalam sistem informasi, broadscope mengacu kepada dimensi fokus, kuantifikasi, dan horison waktu (Glory dan Morton, 1971; Larcker, 1981; Gordon dan Narayanan, 1984) Dalam melaksanakan tugasnya manajer membutuhkan informasi dari berbagai sumber yang sifatnya luas. Karena itu manajer membutuhkan informasi yang memiliki karakteristik broadscope yaitu informasi yang memiliki cakupan yang luas dan lengkap (completeness) yang biasanya meliputi 
aspek ekonomi (pangsa pasar, produk domestik bruto (total penjualan) dan aspek non-ekonomi misalnya kemajuan teknologi, perubahan sosiologis, demografi.

\section{Timeliness}

Menyatakan ketepatan waktu dalam memperoleh informasi mengenai suatu kejadian. Informasi dikatakan tepat waktu apabila informasi tersebut mencerminkan kondisi terkini dan sesuai dengan kebutuhan manajer. Informasi yang tepat waktu akan membantu manajer dalam pengambilan keputusan. Kemampuan para manajer untuk merespon secara tepat terhadap suatu peristiwa kemungkinan dipengaruhi oleh timeliness SIAM. Informasi yang timeliness meningkatkan fasilitas SIAM untuk melaporkan peristiwa paling akhir dan untuk memberikan umpan balik secara tepat terhadap keputusan yang telah dibuat. Jadi, timeliness mencakup frekuensi pelaporan dan kecepatan pelaporan. Chia (1995) menyatakan bahwa teming informasi menunjuk kepada jarak waktu antara permintaan dan tersedianya informasi dari SIAM ke pihak yang meminta.

3. Aggregation

Informasi disampaikan dalam bentuk yang lebih ringkas, tetapi tetap mencakup hal-hal penting sehingga tidak mengurangi nilai informasi itu sendiri. Informasi yang teragregasi akan berfungsi sebagai masukan yang berguna dalam proses pengambilan keputusan, karena lebih sedikit waktu yang diperlukan untuk mengevaluasinya, sehingga meningkatkan efisiensi kerja manajemen. Dalam perkembangan terakhir, agregasi informasi merupakan penggabungan informasi fungsional dan temporal, seperti area penjualan, pusat biaya, departemen produksi dan pemasaran, dan informasi yang dihasilkan secara khusus untuk model keputusan formal.

\section{Integration}

Aspek pengendalian suatu organisasi yang penting adalah koordinasi berba-gai segmen dalam sub organisasi. Karakteristik SIAM yang membantu koordinasi mencakup spesifikasi target yang menunjukkan pengaruh interaksi segmen dan informasi mengenai pengaruh keputusan pada operasi seluruh sub-sub unit organisasi.Informasi yang mencerminkan kompleksitas dan saling keterkaitan antara bagian satu dan bagian lain. Informasi yang terintegrasi berperan sebagai koordinator dalam mengendalikan pengambilan keputusan yang beraneka ragam. Manfaat informasi yang terintegrasi dirasakan penting saat manajer dihadapkan pada situasi di mana harus mengambil keputusan yang akan berdampak pada bagian/unit yang lain.

Masing-masing karakteristik informasi sistem akuntansi itu tidak selalu sama untuk segala situasi. Karakteristik informasi yang tersedia tersebut akan menjadi efektif apabila sesuai dengan tingkat kebutuhan pengguna organisasi. Saling ketergantungan adalah salah satu variabel yang perlu dipertimbangkan dalam merancang SIAM. Menurut Chia (1995) dalam Juniarti dan Evelyne (2003) menyebutkan bahwa manajer yang memiliki informasi dengan karakteristik tersebut umumnya mampu untuk membuat perencanaan yang lebih baik dan mencapai target yang telah ditetapkan. Demikian pula penelitian yang dilakukan oleh Gul dan Chia (1994) dalam Juniarti dan Evelyne (2003) dalam penelitiannya menyimpulkan bahwa ketersediaan karakteristik broadscope dan agregasi atas informasi berkaitan erat dengan kinerja manajemen.

Semakin tinggi tingkat saling ketergantungan akan menyebabkan semakin kompleknya tugas yang dihadapi manajer. Sebagai akibatnya manajer membutuhkan informasi yang lebih banyak, baik itu informasi yang berkaitan dengan departemennya sendiri maupun informasi yang terkait dengan departemen lain. Hayes (1977) dalam Laksmana dan Muslicha (2002)menyatakan bahwa pengukuran kinerja terhadap unit yang mempunyai tingkat saling ketergantungan tinggi akan sangat bermanfaat apabila pengukuran tersebut tidak hanya mencakup penilaian pencapaian target tetapi juga mencakup penilaian reliabilitas, kerjasama, dan fleksibilitas para manajer divisi.

Sebuah penelitian yang dilakukan Davis \& Abright (2000) dengan judul pengaruh teknologi informasi dapat mempengaruhi informasi yang disajikan oleh SIAM. Dengan aplikasi teknologi informasi, SIAM dapat menyediakan informasi sesuai dengan kebutuhan manajemen.

Adanya perbedaan tingkat desentralisasi akan menyebabkan perbedaan kebutuhan informasi. Kondisi tersebut menimbulkan perlunya keselarasan antara tingkat desentralisasi dengan tingkat ketersediaan 
Dampak Karakteristik Sistem Informasi Akuntansi Manajemen Pada Kinerja Manajerial

karakteristik sistem informasi akuntansi manajemen. Apabila perusahaan memiliki tingkat desentralisasi tinggi perlu didukung pula dengan karakteristik informasi sistem informasi akuntansi manajemen yang andal (Mardiyah dan Gudono, 2001).

\section{Kinerja Manajerial}

Kebutuhan akan informasi yang dapat diandalkan serta dapat memberikan ketepatan dalam pengambilan keputusan oleh manajerial merupakan salah satu faktor pendukung dalam meningkatkan kinerja manajerial dan diharapkan akan dapat meningkatkan kinerja perusahaan. Keberhasilan oganisasi dalam mencapai tujuannya sangat tergantung pada manajer. Jika manajer melakukan tugasnya dengan baik maka organisasi tersebut akan mampu mencapai tujuan dan sasaran yang dikehendaki serta meningkatkan keefektifan perusahaan.

Kinerja manajerial merupakan suatu eksistensi dimana manajer mampu menyelesaikan pekerjaan mereka dengan seefektif mungkin (Soobaroyen \& Poorundersing, 2008 dan Ginting, 2010). Seperti menurut Williams (2001), menyatakan bahwa manajemen dalam menjalankan fungsi dan aktivitas bisnisnya meliputi planning (Perencanaan), organizing (Pengorganisasian), actuating (Pengarahan), dan controlling (Pengendalian), senantiasa memerlukan informasi untuk membuat keputusan.

Beberapa pembahasan yang telah mengkaitkan secara langsung pengaruh saling ketergantungan dengan SIAM adalah Chenhall dan Morris (1986) dan Abernethy (2000) menegaskan bahwa semakin tinggi tingkat saling ketergantungan akan menyebabkan semakin kompleknya tugas yang dihadapi manajer. Sebagai akibatnya manajer membutuhkan informasi yang lebih banyak, baik itu informasi yang berkaitan dengan departemennya sendiri maupun informasi yang terkait dengan departemen lain.

Laksmana dan Muslicha (2002) menyatakan bahwa pengukuran kinerja terhadap unit yang mempunyai tingkat saling ketergantungan tinggi akan sangat bermanfaat apabila pengukuran tersebut tidak hanya mencakup penilaian pencapaian target tetapi juga mencakup penilaian reliabilitas, kerjasama, dan fleksibilitas para manajer divisi.

Disamping itu, Juniarti dan Evelyne (2003) dalam penelitiannya menemukan hasil bahwa terdapat pengaruh yang signifikan antara karakteristik informasi (scope, aggregation, timeliness, dan integration) terhadap kinerja manajerial jika dilihat dari kemampuan manager dalam mencapai target produksi. Kinerja manajerial dalam hal kemampuan manajer dalam membuat perencanaan dipengaruhi hanya dua karakteristik informasi timeliness dan integration. Jadi, karakteristik informasi SIAM berpengaruh terhadap kinerja manajerial.

\section{Pengukuran Kinerja Manajerial}

Kinerja manajerial adalah ukuran seberapa efektif dan efisien manajer telah bekerja untuk mencapai tujuan organisasi (Stoner, 1992) dalam Ginting (2010). Evaluasi atas kinerja yang dilakukan oleh manajer beragam tergantung pada budaya yang dikembangkan masing-masing perusahaan. Juniarti et al (2003:113) mengemukakan beberapa ukuran yang digunakan dalam mengevaluasi kinerja manajemen berdasarkan perspektif non keuangan sebagai berikut:

1. Kemampuan manajer untuk membuat perencanaan. Perencanaan yang baik dapat meningkatkan fokus dan fleksibilitas manajer dalam manangani pekerjaannya. Masalah fokus dan fleksibilitas merupakan dua hal penting dalam lingkungan persaingan yang tinggi dan dinamis. Kemampuan manajer dalam membuat perencanaan dapat menjadi salah satu indikator untuk mengukur kinerja manajer.

2. Kemampuan untuk mencapai target. Kinerja manajer dapat diukur dari kemampuan mereka untuk mencapai apa yang telah direncanakan (Mulyadi, 2001:302). Target harus cukup spesifik, melibatkan partisipan, realistik dan menantang serta memiliki rentang waktu yang jelas.

3. Kiprah manajer di luar perusahaan. Intensitas manajer dalam mewakili perusahaan untuk berhubungan dengan pihak luar menunjukkan kepercayaan perusahaan kepada manajer tersebut. Kepercayaan ini dapat timbul karena beberapa hal salah satunya adalah kinerja yang baik dari manajer. Wagner (1995) juga mengungkapkan bahwa peranan manajer dalam 
mewakili perusahaan menunjukkan tingkat kinerjanya. Selain itu, pengukuran kinerja manajemen dapat dilihat dari perspektif finansial. Menurut Laksmana dan Muslichah (2000), ukuran yang paling sering digunakan dalam pengukuran kinerja melibatkan ukuran akuntansi dan menggunakan anggaran sebagai standar terhadap kinerja yang dihasilkan.

\section{Metode Pengukuran Kinerja Manajerial}

Agar tujuan yang telah ditetapkan perusahaan dapat diketahui telah tercapai atau tidak maka diperlukan sistem pengukuran kinerja manajerial yang tepat. Dengan adanya sistem pengukuran kinerja maka diharapkan manajer dapat selalu meningkatkan atau memaksimalkan kinerja yang dimilikinya, karena dengan adanya sistem pengukuran kinerja manajer dapat mengetahui bahwa kinerjanya akan dinlai, oleh karena itu sistem pengukuran kinerja merupakan salah satu faktor yang mempengaruhi kinerja manajeral. Kinerja manajerial perusahaan yang bagus akan bersinergi terhadap kualitas produk atau jasa yang diharapkan pelanggan. Jadi kinerja manajerial dipengaruhi oleh interaksi antara sistem akuntansi manajemen dan sistem pengukuran kinerja.

Kinerja manajerial perusahaan dapat diukur dengan:

\section{Balanced Scorecard}

Balanced Scorecard merupakan salah satu pendekatan yang digunakan untuk mengukur kinerja manajemen. Pada awal sekitar tahun 90an balanced scorecard ditemukan dan digunakan oleh Robert S. Kaplan dan David P. Norton sebagai alat pengukuran kinerja manajemen pada perusahaanperusahaan swasta di Amerika.

Menurut Kaplan dan Norton (1996) balanced scorecard adalah suatu kerangka kerja baru untuk mengintegrasikan berbagai ukuran yang diturunkan dari strategi perusahaan. Balanced Scorecard merupakan suatu alat yang mempunyai tiga elemen, yaitu sistem pengukuran (measurement system), sistem manajemen stratejik (strategic management system), dan alat komunikasi (communication tool). (Paul R. Niven, 2003: 15).

Dengan menggunakan Balanced Scorecard, pimpinan organisasi dapat mengukur seberapa efektif unit organisasi mereka dalam membentuk nilai bagi pelanggan pada saat sekarang dan masa depan, membangun dan meningkatkan kapabilitas internal, dan mengembangkan sumber daya manusia, sistem, dan prosedur yang diperlukan untuk meningkatkan kinerja pada masa yang akan dating.

Menurut Robert Simon (2000) dengan menggunakan keempat perspektif tersebut, akan memberikan keseimbangan pada: (1) tujuan jangka pendek dan tujuan jangka panjang; (2) ukuran eksternal (yaitu untuk pemilik dan pelanggan) dan ukuran internal yaitu pada proses bisnis internal, inovasi, dan pembelajaran dan pertumbuhan; (4) ukuran kinerja yang tegas dan lebih lembut, ini lebih bersifat subyektif. Keseimbangan dalam Balanced Scorecard dapat dilihat pada Gambar dibawah ini:

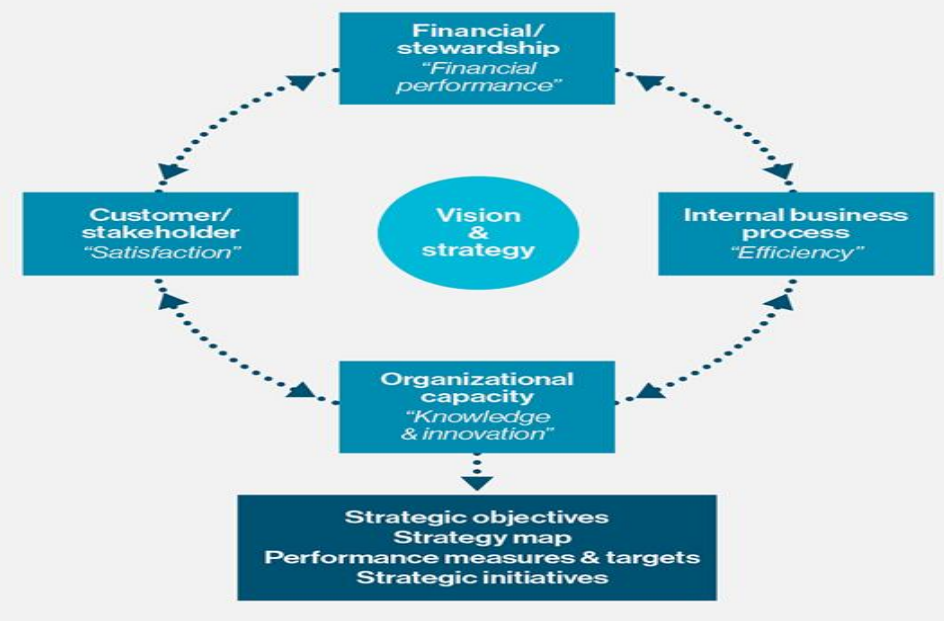

Gambar 1 Sistem menggunakan Balance Scorecard (Kaplan \& Northon, 1996) 
Dengan demikian tersedianya karakteristik sistem informasi akuntansi manajemen (SIAM), memungkinkan manajer untuk mengambil keputusan secara tepat dan cepat yang pada akhirnya dapat meningkatkan kinerja manajerial.

\section{Total Quality Management (TQM)}

Kualitas menjadi hal utama yang menjadi titik fokus setiap perusahaan. Berbagai hal dilakukan untuk meningkatkan kualitas yang diterapkan pada produk, pelayanan dan manajemen perusahaan. Seiring dengan perkembangan ilmu pengetahuan, lahirlah suatu inovasi yang dikenal dengan TQM.

Tjiptono dan Anastasia (2003:4), menyatakan bahwa "TQM merupakan suatu pendekatan dalam menjalankan usaha yang mencoba untuk memaksimalkan daya saing organisasi melalui perbaikan terusmenerus atas suatu produk, jasa, manusia, proses dan lingkungannya. TQM juga merupakan suatu sistem yang sat ini mulai diterapkan oleh perusahaan-perusahaan karena dianggap mampu mendukung kinerja manjerialnya". Total quality management adalah suatu sistem manajemen yang berorientasi pada pelanggan yang bertujuan untuk meningkatkan kepuasan pelanggan secara berkelanjutan melalui eliminasi pemborosan, meningkatkan kualitas, pengembangan ketrampilan dan mengurangi biaya produksi. (Kurnianingsih dan Indrianto, 2001:35).

Menurut Nasution (2004:22), dalam penerapan TQM, ada 5 unsur utama yang dikembangkan oleh Goetsch dan Davis (1994) dijelaskan sebagai berikut

Mengukur kinerja manajerial dalam perspektis atas pandangan TQM:

1. Fokus pada pelanggan

Menurut Tjiptono dan Anastasia (2001:101), pada hakikatnya tujuan bisnis adalah untuk menciptakan dan mempertahankan para pelanggan. Dalam pendekatan TQM, kualitas ditentukan oleh pelanggan.

2. Perbaikan berkesinambungan

Menurut Tjiptono dan Anastasia (2001:262), "Perbaiakn yang berkesinambungan merupakan slah satu unsur paling fundamental dari TQM. Konsep ini diterapkan baik terhadap proses produk maupun orang yang melakukannya.

3. Perbaikan dan Pelatihan

Menurut Tjiptono dan Anastasia (2001:212), "Pelatihan merupakan bagian dari pendidikan. Pendidikan lebih bersifat filosofis dan teoritis. Walaupun demikian, pendidikan dan pelatihan memiliki tujuan yang sama, yaitu pembelajaran.

4. Obsesi terhadap kualitas

Dengan adanya kualitas yang telah ditetapkan, organisasi harus terobsesi untuk memenuhi atau melebihi apa yang telah ditentukan sebelumnya. Hal ini berarti bahwa semua karyawan pada tiap level berusaha melaksanakan setiap aspek pekerjaannya berdasarkan perspektif untuk melakukan segala sesuatunya dengan lebih baik.

5. Adanya komitmen

Komitmen jangka panjang sangat penting guna mengadakan perubahan budaya agar penerapan TQM dapat berjalan dengan sukses.

Menurut Mulyadi (2001), manfaat sistem pengukuran kinerja adalah sebagai berikut:

a. Mengelola operasi organisasi secara efektif dan efisien melalui pemotivasian karyawan secara maksimum.

b. Membantu pengambilan keputusan yang bersangkutan dengan karyawan seperti promosi, pemberhentian dan mutasi.

c. Mengidentifikasi kebutuhan pelatihan dan pengembangan karyawan dan untuk menyediakan kriteria seleksi dan evaluasi program pelatihan karyawan.

d. Menyediakan umpan balik bagi karyawan mengenai bagaimana atasan mereka menilai kinerja mereka.

e. Menyediakan suatu dasar bagi distribusi penghargaan. 
Dengan beragamnya informasi yang diterima oleh manajemen, maka perlu dipilih dan dikelompokkan karakteristik informasi yang dapat memberikan kontribusi dalam pencapaian kinerja manajemen. Karakteristik yang berupa aggregation, broad-scope, integration dan timeliness mampu meningkatkan kinerja manajer. Manajer yang memiliki informasi dengan karakteristik tersebut umumnya mampu untuk membuat perencanaan yang lebih baik dan mencapai target yang telah ditetapkan. Hal ini khususnya lebih nampak pada organisasi-organisasi yang terdesentralisasi (Chia, 1995:812).

Hasil Penelitian Achmad dan Ira (2009) menggunakan karakteristik akuntansi berupa broadscope, timeliness, aggregation, dan integration membuktikan secara parsial terdapat pengaruh positif signifikan antara karakteristik sistem informasi akuntansi manajemen terhadap kinerja manajerial. Retno (2000) menguji dan membuktikan bahwa praktik-praktik pemanufakturan TQM dan sistem akuntansi manajemen secara interaktif mempengaruhi kinerja manajerial. Namun penelitian yang dilakukan oleh Nopalia, Putra, dan Fitriani (2012), bertentangan dengan penelitian sebelumnya, kenyataan ini menunjukkan bahwa tidak ada sistem akuntansi manajemen secara universal yang selalu tepat untuk bisa diterapkan pada seluruh organisasi di setiap keadaan, namun sistem akuntansi tergantung juga pada faktor-faktor kondisional yang ada dalam organisasi tersebut.

Sesuai dengan pernyataan Bodnar (1995) dalam Juniari dan Evelyn (2003) yang menyatakan bahwa informasi dikatakan tepat waktu apabila informasi tersebut mencerminkan kondisi terkini dan sesuai dengan kebutuhan manajer. Sehingga dapat dikatakan dengan tersedianya informasi pada saat yang tepat dapat menunjang kegiatan manajer dalam meningkatkan kinerja perusahaan.

Dengan demikin, semakin tinggi aplikasi teknologi system informasi akuntansi manajemen, semakin meningkatkan kemampuan suatu system untuk menyajikan informasi sesuai dengan kebutuhan manajer dalam pengambilan keputusan. Ini akan memberikan semakin banyak alternatif solusi yang dapat dipertimbangkan oleh manajer dalam pengambiln keputusan sehingga kinerja manajerial dapat ditingkatkan.

\section{Dampak Karakteristik Informasi Sistem Akuntansi Manajemen pada Kinerja Manajerial}

Persaingan bisnis yang meningkat dewasa ini menuntut perusahaan untuk memanfaatkan kemampuan yang ada semaksimal mungkin, agar unggul dalam persaingan. Keunggulan daya saing yang dapat diciptakan oleh perusahaan dapat dicapai dengan salah satu cara, yaitu meningkatkan kinerja manajerial (Widarsono, 2007). Untuk dapat meningkatkan kinerja tersebut, maka manajemen perlu memiliki kemampuan untuk melihat dan menggunakan peluang, mengidentifikasikan permasalahan, dan menyeleksi serta mengimplementasikan proses adaptasi dengan tepat.

Dalam mencapai tujuan tersebut diperlukan suatu sistem informasi yang terarah dan teritegrasi dengan baik. Perencanaan sistem informasi merupakan bagian dari sistem pengendalian organisasi perlu mendapatkan perhatian, sehingga bisa diharapkan memberikan kontribusi positif didalam mendukung keberhasilan sistem pengendalian organisasi. Salah satu fungsi dari sistem informasi adalah menyediakan informasi penting untuk membantu manajer mengendalikan aktivitasnya, serta mengurangi ketidakpastian lingkungan, sehingga diharapkan dapat membantu perusahaan ke arah pencapaian tujuan dengan sukses (Atkinson dkk., 1995). Informasi yang dihasilkan suatu sistem informasi merupakan sumberdaya bagi organisasi, dimana informasi tersebut dapat mendukung manajemen dalam pengambilan keputusan (Widarsono, 2007).

Semakin berkualitas informasi diperoleh manajemen, kemudian informasi tersebut dijadikan dasar pengelolaan usaha, maka akan meningkatkan kemampuan manajemen tersebut untuk meraih kesuksesan usaha. Hal tersebut menjelaskan adanya pengaruh Karakteristik Informasi dengan Kinerja Manajerial. Pernyataan tersebut diperkuat oleh penelitian Juniarti dan Evelyne (2003), yang menyatakan bahwa keputusan yang didasarkan pada informasi yang berkualitas, akan berdampak kepada peningkatan kinerja manajerial. Juniarti dan Evelyne (2003) menyimpulkan bahwa terdapat hubungan yang signifikan antara karakteristik informasi (scope, aggregation, timeliness, dan integration) dengan kinerja manajerial. Juniarti dan Evelyne (2003) juga menyimpulkan bahwa dengan menggunakan variabel dan indikator yang sama akan menunjukkan bahwa terdapatnya 
pengaruh antara karakteristik informasi dengan kinerja manajerial. Hal ini berarti karakteristik informasi SIAM berdampak pada kinerja manajerial, dampak dari karakteristik informasi SIAM tersebut adalah sangat positif, yaitu dapat meningkatkan kinerja manajerial.

Manajer yang memiliki informasi dengan karakteristik tersebut umumnya mampu untuk membuat perencanaan yang lebih baik dan mencapai target yang telah ditetapkan. Demikian pula penelitian yang dilakukan oleh Gul dan Chia (1994) dalam Juniarti dan Evelyne (2003) dalam penelitiannya menyimpulkan bahwa ketersediaan karakteristik broadscope dan agregasi atas informasi berkaitan erat dengan kinerja manajemen. Dengan kata lain, bahwa keberadaan kedua karakteristik ini mampu meningkatkan kinerja manajemen.

Dampak masing-masing karakteristik SIAM pada kinerja manajerial dapat ditunjukkan antara lain adalah sebagai berikut:

1. Broadscope. Unsur broadscope berarti informasi yang memiliki cakupan yang luas dan lengkap (completeness), mempunyai tiga subdimensi yaitu fokus, kuantifikasi, dan waktu.

a. Fokus merupakan informasi yang berasal dari dalam atau luar organisasi berhubungan dengan faktor ekonomi (seperti total penjualan, pangsa pasar, dan lain-lain), kemajuan teknologi, perubahan sosial, perkembangan demografi.

b. Kuantifikasi (Quantification) merupakan informasi yang berkenaan dengan keuangan dan bukan keuangan.

c. Waktu (Time Horizon) merupakan informasi yang berkaitan dengan informasi yang akan datang.

Pada biasanya meliputi seluruh informasi tentang biaya operasional, tentang kondisi sumber daya manusia serta laporan tentang tanggung jawaban masing-masing divisi. Informasi yang memiliki karakteristik broadscope dapat meningkatkan kinerja manajerial.

2. Timeliness. Unsur timeliness berarti informasi yang tepat waktu saat pelaporannya. Karena informasi yang tepat waktu akan membantu manajer dalam pengambilan keputusan. Informasi yang memiliki karakteristik timelinessdapat meningkatkan kinerja manajerial.

3. Aggregation. Unsur aggregationberarti informasi disampaikan dalam bentuk yang lebih ringkas, tetapi tetap mencakup hal-hal penting sehingga tidak mengurangi nilai informasi itu sendiri. Fungsinya untuk menambah informasi dalam proses pengambilan keputusan, karena lebih sedikit waktu yang diperlukan untuk mengevaluasinya, sehingga meningkatkan efisiensi kerja manajemen. Informasi yang memiliki karakteristik aggregation dapat meningkatkan kinerja manajerial.

4. Integration. Unsur integration berarti informasi yang mencerminkan kompleksitas dan saling keterkaitan antara bagian satu dan bagian lain. Fungsinya berperan sebagai koordinator dalam mengendalikan pengambilan keputusan yang beraneka ragam. Manfaatnya dirasakan penting saat manajer dihadapkan pada situasi dimana harus mengambil keputusan yang akan berdampak pada bagian/unityang lain.

Informasi yang memiliki karakteristik integration dapat meningkatkan kinerja manajerial. Karakteristik terintegrasi atau terpadu memberikan sarana koordinasi atar segmen dalam sub unit atau antar sub unit dalam organisasi. Semakin banyak jumlah segmen dan unit bisnis dalam organisasi akan semakin besar kebutuhan informasi karakteristik integrasi dan SIAM (Budiarto, 2007). Informasi yang mencerminkan kompleksitas dan saling keterkaitan antara bagian satu dan bagian lain. Informasi yang terintegrasi berperan sebagai koordinator dalam mengendalikan pengambilan keputusan yang beraneka ragam (Chia, 1995).

Para manajer membutuhkan sistem informasi akuntansi manajemen yang andal, informasi yang bersifat integritas (satu kesatuan) agar mampu menyediakan kebutuhan informasi yang tepat waktu dan relevan dalam pembuatan kebijakan yang efektif, membantu manajer untuk mengatasi kompleksitas tugas yang dihadapi sehingga menghasilkan kinerja manajerial yang lebih tinggi (Chia, 
1995). Karakteristik SIAM memainkan peran yang penting. SIAM didesain untuk memberikan informasi yang lebih canggih dan tidak hanya membantu membuat keputusan dalam departemen, namun juga membantu koordinasi antar departemen (Bowens dan Abernethy, 2000)

Juniarti et al (2003:113) mengungkapkan dalam penelitiannya mengenai hubungan karakteristik informasi yang dihasilkan oleh sistem informasi akuntansi manajemen terhadap kinerja manajerial secara umum menunjukkan bahwa terdapat korelasi antara karakteristik informasi yang terdiri dari broadScope, agregasi, integrasi dan Timeliness dengan kinerja manajerial yang terdiri dari kemampuan manajer dalam membuat perencanaan, mencapai target dan melakukan kiprahnya diluar perusahaan sebagai indikator, meskipun tingkat hubungan tersebut bervariasi tergantung pada kebutuhan manajer dalam mencapai kinerja mereka.

Nazaruddin (1998) yang menguji mengenai pengaruh karakteristik informasi yang dihasilkan oleh sistem akuntansi manajemen terhadap kinerja manajerial menunjukkan bahwa tingkat keandalan karakteristik sistem akuntansi manajemen (broad Scope, Timeliness, agregasidan integrasi) mempunyai pengaruh yang signifikan terhadap kinerja manajerial

Mulyadi dan Setyawan (2000) dalam Laksmana dan Muslicha (2002) menyatakan bahwa penggunaan informasi akuntansi yang tidak tepat dalam pengukuran kinerja sering menghasilkan perilaku yang tidak baik, dan bisa berakibat negatif. Kesulitan dalam penentuan dan penghargaan perilaku manajerial yang layak mengakibatkan perlunya monitoring dan penghargaan atas kerja.

Para manajer membutuhkan MAS yang dapat memberikan informasi yang bersifat integritas (satu kesatuan).

\section{KESIMPULAN DAN SARAN}

Sistem Informasi Akuntansi Manajemen (SIAM) merupakan sistem formal yang dirancang untuk menyediakan informasi, sehingga membantu manajer dalam pengendalian aktivitas dan pengurangan ketidakpastian untuk membantu perusahaan pencapaian tujuan jangka panjang dan tujuan jangka pendek. Semakin berkualitas informasi diperoleh manajemen, kemudian informasi tersebut dijadikan dasar pengelolaan usaha, maka akan meningkatkan kemampuan manajemen tersebut untuk meraih kesuksesan usaha. Perencanaan sistem informasi merupakan bagian dari sistem pengendalian organisasi perlu mendapatkan perhatian, sehingga bisa diharapkan memberikan kontribusi positif didalam mendukung keberhasilan sistem pengendalian organisasi. Manajer yang memiliki informasi dengan karakteristik scope, timeliness, aggregation, dan integration pada umumnya mampu untuk membuat perencanaan yang lebih baik dan mencapai target yang telah ditetapkan. Ketersediaan karakteristik broadscope dan agregasi atas informasi berkaitan erat dengan kinerja manajemen. Semakin broadscope, timeliness, aggregation, dan integration suatu informasi semakin besar pula dampaknya terhadap kinerja manajerial.

Kirmizi Ritonga \& Yusserrie Zainuddin (2001) menuliskan bahwa kinerja organisasi merupakan kemampuan organisasi untuk mencapai objektif sebagai akibat menggunakan atau mengimplementasikan SIAM. Aspek pengendalian suatu organisasi yang penting adalah koordinasi berba-gai segmen dalam sub organisasi. Karakteristik SIAM membantu koordinasi mencakup spesifikasi target yang menunjukkan pengaruh interaksi segmen dan informasi mengenai pengaruh keputusan pada operasi seluruh sub-sub unit organisasi.

\section{Referensi}

1. Abernethy, M.A. dan Cameron H. Guthrie, 1994. "An Empirical Assessment of the "Fit" between Strategy and Management Information System Design", Accounting and Finance, November, pp. 49-66.

2. Achmad, S dan Ira S.,2009. "Pengaruh Karakteristik Sistem Informasi Akuntansi Manajemen dan Desentralisasi Sebagai Variabel Moderating terhadap Kinerja Manajerial (Studi Empiris Perusahaan Manufaktur di Kabupaten Semarang)". Fokus Ekonomi, Vol.4 No. 1, Juni, PP 64-74. 
3. Anthony, R.N., Dearden, J. dan Bedford, N.M., 1998. Management Control Systems, Homewood, Illinois: Irwin

4. Bouwens, J. Dan Abernethy, MA., 2000. "The Consequences of Customization on Management Accounting System Design." Accounting Organization and Society. Vol.15, pp.221-241.

5. Budiarto, Dekeng Setyo,2007. "Pengaruh Karakteristik Sistem Informasi Akuntansi Manajemen Terhadap Kinerja Organisasi Dengan Tingkat Desentralisasi Sebagai Variabel Moderating". Jurnal Ekonomi Janavisi, Vol.10, No.2. Pp.134-151.

6. Chenhall, R.H and Morris D., 1986. "The Impact of Structure, Environment, and Interdependence on The Perceived Usefulness of Management Accounting System". The Accounting Review. Vol. 6, No. 1. January. Pp. 16-35.

7. Chia, Y.M., 1995. "Decentralization, Management Accounting System Information Characteristic and Their Interaction Effect On Managerial Performance : A Singapore Study", Journal of Business Finance and Accounting, pp 811-830.

8. Davis, Stan, dan Tom Albright, 2000. "The Changing Organizational Structure And Individual Responsibilities of Managerial Accountants: A Case Study", Journal of ManagerialIssues, Vol.12, No.4, pp. 446-467.

9. Faisal, 2006. "Analisis Pengaruh Intensitas Persaingan Dan Variabel Kontekstual Terhadap Penggunaan Informasi Sistem Akuntansi Manajemen Dan Kinerja Unit Bisnis Dengan Pendekatan Partial Least Square". Simposium Nasional Akuntansi 9 Padang. Pp. 1 - 25.

10. Ginting, H. S., 2010. Pengaruh Partisipasi Anggaran dan Kejelasan Sasaran Anggaran Terhadap Kinerja Aparat Perangkat Daerah di Pemerintahan Kabupatan Karo, Tesis Sekolah Pascasarjana Universitas Sumatera Utara Medan

11. Gordon, L.A. dan V.K. Narayanan, 1984. "Management Accounting System: Perceived Environmental Uncertainty and Organisation Structure: An Empirical Investigation", Accounting, Organizations and Society, Vol.9, pp.33-47.

12. Gorry, G. dan Scott M. Morton, 1971. "A Framework for Management Information Systems", Sloan Management Review, Fall, pp.55-70.

13. Guimaraes, Tor, Sandy D Staples., dan James D Mckeen, 2003. "Empirically Testing Some MainUser Related Factors for System Development Quality". The Quality Management Journal. ABI/INFORM Global. hal $39-55$.

14. Hansen, D.R. dan Maryanne M. Mowen, 1997. "Management Accounting, Fourth ed"., International Thomson Publishing.

15. Juniarti, dan Evelyne, 2003. Hubungan karakteristik informasi yang dihasilkan oleh system informasi akuntansi manajemen terhadap kinerja manajerial pada perusahaan manufaktur di Jawa Timur, Jurnal Akuntansi dan Keuangan, Vol.5. No.2, November: 110-122.

16. Kurnianingsih, R. dan N. Indriantoro, 2001. 'Pengaruh Sistem pengukuran Kinerja dan system Penghargaan terhadap keefektifan penerapan teknik total quality Manajemen". Jurnal Riset Akuntansi Indonesia.

17. Laksmana, A., dan Muslicah, 2002. "Pengaruh Teknologi Informasi, Saling Ketergantungan, Karakteristik Sistem Akuntansi Manajemen Terhadap Kinerja Manajerial". Jurnal Akuntansi dan Keuangan, Vol.4, No.2, November: 106-125.

18. Mia, Lokman dan Robert H. Chenhall, 1994. "The Usefulness of Management Accounting Systems, Functional Differentiation and Managerial Effectiveness", Accounting Organizations and Society, Vol.19, No.1, pp.1-13.

19. Mulyadi, 2001. Balanced Scorecard, Cetakan Kesatu, Jakarta: Salemba Empat

20. Muslichah, 2003. "Pengaruh Variabel Kontinjensi Terhadap Karakteristik Sistem Akuntansi Manajemen Dan Kinerja Manajerial Pada Unit Bisnis Industri Manufaktur Di Jawa Timur". Tesis Airlangga University Library Surabaya

21. Nazaruddin, Letje, 1998. "Pengaruh Desentralisasi dan Karakteristik Informasi Sistem Akuntansi Manajemen Terhadap Kinerja Manajerial". Jurnal Riset Akuntansi Indonesia. Vol.1 No.2, Juli, PP 141-162. 
22. Nopalia dkk, 2012. "Pengaruh Penggunaan Informasi Akuntansi Manajemen dan Kepribadian Tanjung Perak". e-jurnal Binar Akuntansi Vol. 1 No. 1 September.

23. Pearson, JM., McCohan dan Hightower, 1995. "Total Quality Management: Are Information System Managers Ready?"Information System Management hal 251- 263

24. Soobaroyen, T. And Poorundersing, 2008. "The Effectiveness of Management Accounting Systems. Evidence fro, unctional managers in a Developing Country". Managerial Auditing Journal. Vol. 23. No. 2. Pp 187-219

25. Tjiptono, F. dan Aanastasi, D., 1994. "Total Quality Management". Yogyakarta: Penerbit Andi.

26. Widarsono, Agus, 2007. "Pengaruh Kualitas Informasi Manajemen Terhadap Kinerja Manajerial". 